\title{
BŪSIMŲ SOCIALINIŲ DARBUOTOJŲ NUOSTATOS I SAVANORIŠKĄ VEIKLĄ: LIETUVOS IR SUOMIJOS PATIRTIS
}

\author{
Ilona Kupčikienė, Eglẻ Stasiūnaitienė, Sandra Palažijūtė \\ Kauno kolegijos Medicinos fakultetas
}

Raktažodžiai: savanoriška veikla, nuostata, socialinis darbuotojas.

\begin{abstract}
Santrauka
Šiuolaikinejje visuomeneje vis daugiau dèmesio skiriama savanoriškos veiklos praktikai, kuri sudaro galimybes sustiprinti turimus ir igyti naujų socialinių gebejjimų, aktyviai dalyvauti visuomeninio gyvenimo veiklose. Dalyvavimo savanoriškoje veikloje pasirinkimą sąlygoja asmens turima patirtis bei asmeninès nuostatos. Straipsnyje analizuojama nuostatos samprata, apibūdinama savanoriška veikla socialinio darbo kontekste. Straipsnio turinyje nagrinejjamos būsimų socialinių darbuotojų nuostatos ị savanorišką veiklą remiantis nuostatos kognityviniu, emociniu ir elgesio komponentais, lyginama respondentų iš Lietuvos ir Suomijos patirtis. Empirinio tyrimo metu nuostatos tyrinejjamos žvelgiant iš kognityvinio (pažintinio), afektinio (emocinio) ir elgesio komponentų perspektyvos. Kognityvinis komponentas - tai nuomonès, isitikinimai, kurių laikomasi tam tikrų žmonių ir dalykų atžvilgiu. Afektinis komponentas apima malonias arba nemalonias emocijas, susijusias su ịsitikinimais. Jos suteikia nuostatai emocinị atspalvị ir nulemia veiksmą, kurị ketiname įvykdyti. Šis veiksmas ir yra nuostatos elgesio komponentas, kuris sąlygoja asmens reakciją, atitinkančią jo ịsitikinimus ir išgyvenimus. Pažinimo komponentai susideda iš asmens žinių apie nuostatos objektą. Žinios, informacija yra vienas iš nuostatas formuojančių veiksnių. Informacijos pateikimas apie nuostatos objektą keičia jo suvokimą, interpretaciją. Nuostatos pažinimo komponentas neatsiejamas nuo jausminès srities. Emocinis nuostatos komponentas gali skatinti arba slopinti pažintinès informacijos prièmimą ir, atvirkščiai, žinios turi įtakos emociniam komponentui. Platesnè, išsamesnè informacija mažina stereotipinių nuostatų formavimąsi.
\end{abstract}

\section{Ivadas}

Socialinio darbo profesijos raida susijusi su savanoriškų organizacijų veikla XIX a. pabaigoje - XX a. pradžioje. Socialinio darbo, kaip profesinès veiklos, jungiančios asmeninius, socialinius ir specialiuosius gebejimus, sékmè priklauso ne tik nuo profesionalios, bet ir nuo savanoriškos veiklos. Savanoriška veikla - savanorio neatlyginamai atliekama visuomenei naudinga veikla, kurios sąlygos nustatomos savanorio ir šios veiklos organizatoriaus susitarimu. Savanoriška veikla egzistuos tol, kol bus tokios pagalbos poreikis. Savanoriškos veiklos pagrindai ir pasirengimas praktikai turètų būti neatskiriama socialinių darbuotojų profesionalaus parengimo dalis. Šiuolaikinèje visuomenejje vis stipriau įsitvirtina nuostata, kad savanoriška veikla - tai būdas aktyviai dalyvauti visuomenès gyvenime, prisidèti sprendžiant ịvairias problemas. Savanoriška veikla, ịsitraukimas i ją arba ne, savaime suprantama, pirmiausia priklauso nuo asmeninių nuostatų ir pasirinkimo [9].

Pagrindinis ịrankis, kurị turi socialinis darbuotojas, yra jo žinios, gebejjimai, profesinès bei asmeninès vertybinès nuostatos bei požiūriai. Neidentifikuoti požiūriai veikia bendravimą su kitais ir gebejjimą padèti [6]. Pastebèta, kad nèra svarbu, kokiomis teorijomis remiamasi bei kokie metodai naudojami profesineje veikloje, - savanoriškos pagalbos efektyvumą žymiai labiau veikia tai, kaip teikiantis pagalbą asmuo suvokia vyraujančias savo asmenines ir profesines nuostatas, kurioms įtakos turi asmeninè ir profesinè patirtis, socialinis kontekstas [1,19].

Mus supančio išorinio pasaulio aiškinimas ir vertinimas remiasi mūsų nuostatomis, kurios formuojasi per visą žmogaus raidos laikotarpic. Nuostatos - mūsų gyvenimo orientyrai, kuriais vadovaujamès, kai susiduriame su tam tikrais žmonėmis, îvykiais ar pranešimais [3].

Pateikiama ịvairių nuostatos sampratų. Dažniausiai socialinès psichologijos literatūroje autoriai pateikia, kad nuostata - tai iqsitikinimas ir jausmas, kurie parengia tam tikru būdu reaguoti ị daiktus, žmones ar įvykius. D. G. Myers pažymi, kad nuostata-palanki arba nepalanki kokio nors dalyko ar asmens vertinimo reakcija, dažnai grindžiama įsitiki- 
nimais, o išreiškiama jausmais ir elgesio ketinimais $[3,13]$.

Dauguma socialinės psichologijos tyrèjų, apibrèždami nuostatos sampratą, vadovaujasi trimačiu nuostatos modeliu. Nuostatos struktūrą sudaro kognityvinis, emocinis ir elgesio komponentai [8]. Kognityvinis komponentas - tai nuomonès, ìsitikinimai, kurių mes laikomès tam tikrų žmonių ir dalykų atžvilgiu. Jų pagalba mes sprendžiame, kas yra teisinga, tikètina, i ką tai panašu. Emocinis komponentas apima malonias arba nemalonias emocijas, susijusias su ịsitikinimais. Jos suteikia nuostatai emocinị atspalvị ir nulemia veiksmą, kurị ketiname įvykdyti. Tas veiksmas ir yra nuostatos elgesio komponentas, kuris sąlygoja žmogaus reakciją, atitinkančią jo įsitikinimus ir išgyvenimus $[13,18]$.

Ryšys tarp nuostatos kognityvinio ir elgesio komponentų yra dvipusis. Elgesys paprastai daro stipresnę įtaką kognityviniam komponentui, nei nuomonès, įsitikinimai elgesiui. Elgesys gali tiek formuoti kognityvinị komponentą, tiek jị keisti. Dažnai mūsų nuostatos susiformuoja mums interpretuojant savo elgesi $[10,11]$.

Atskiru asmenų nuostatos priklauso nuo grupių, kuriose jie veikia (šeimos, mokyklos, organizacijos ir k.t.), nuo asmenybès amžiaus, gabumų ir sugebèjimų, nuo profesinès veiklos ypatybių, masinès informacijos skleidžiamų nuostatų ir kitų vidinių bei išorinių sąlygų [18].

Savanoriška veikla apibréžiama kaip laisva valia pasirenkama ir pinigais neatlyginama visuomenès labui skirta veikla, atliekama tiek nevyriausybinèse, tiek biudžetinèse organizacijose ar dirbant individualiai [12]. Tai galimybė kiekvienam, nepriklausomai nuo lyties, tautybès, religinių bei politinių issitikinimų, amžiaus ir sveikatos panaudoti savo žinias ir patirtį, realizuoti savo pomėgius, susirasti naujų draugų, igyti naujų žinių bei igūdžių, būti reikalingam kitiems, gerai praleisti laisvalaikị, issitraukti ị darbą ir dalyvauti visuomenės gyvenime, keičiant ji pagal bendruomenès poreikius. Pagrindinis savanoriškos veiklos tikslas socialinè, pedagoginè, psichologinè pagalba žmonèms, siekiant jų sèkmingesnès socializacijos bendruomenèje $[9,15]$.

Laisva valia, materialinès naudos nebuvimas ir nauda trečiajai šaliai - tai pagrindiniai kriterijai, skiriantys savanorišką veiklą nuo kitų. Šiuolaikinejje visuomenejje vis stipriau ịsitvirtina nuostata, kad savanoriška veikla - tai būdas aktyviai dalyvauti visuomenès gyvenime, prisidèti sprendžiant ịvairias problemas. Savanoriška veikla, ịsitraukimas i ją arba ne, priklauso nuo asmeninių nuostatų ir pasirinkimo. Savanoriška veikla pasaulyje yra pripažinta ir vertinama kaip labai svarbi visuomenès veiklos dalis, atnešanti naudą ne tik savanoriams, bet ir savanorius priimančioms organizacijoms bei visai valstybei [17].

Savanoriai istoriškai buvo labai svarbus šaltinis teikiant socialines paslaugas. Prieš susiformuojant socialinio darbuotojo profesijai, daugumą socialinių paslaugų teiké savanoriai [6] . Savanoryste kiekvienoje socialinejje srityje suformuoja tam tikrą jautrumą ir kompetenciją žmonių grupèms ir reiškiniams, su kuriais susiduriama. Savanoryste skatina atsisakyti stereotipų, išankstinių nuostatų, leidžia atpažinti kiekvieno žmogaus vertę [15].

Savanoriška pagalba papildo profesionaliają pagalbą, taigi pagrindinè savanoriu funkcija - bendravimas ir bendradarbiavimas su įvairiomis bendruomeneje egzistuojančiomis institucijomis, kur dirba profesionalūs socialiniai darbuotojai, tarpininkaujant tarp asmens ir institucijos, tarp asmens ir profesionalo, siekiant igalinti bendruomenę efektyvinti paslaugas $[7,16]$.

Savanoriška veikla suprantama ịvairiai visoje Europoje, priklausomai nuo kultūrinio, istorinio ir teisinio šalies konteksto. Veikla, kuri yra vertinama vienoje šalyje, galbūt nèra vertinama kitoje [20]. Siekiant geriau suprasti savanoriškos veiklos svarbą ir vyraujančias nuostatas i ją, tikslinga atsižvelgti ị kitų šalių turimą patirtị, tradicijas ir socialinę, ekonominę situaciją.

Savanoriška veikla Lietuvoje nẻra plačiai paplitusi dèl to, kad sovietų režimas trukdè formuotis stipriai, organizuotai pilietinei visuomenei bei savarankiškam NVO sektoriui. Taip pat lèmè ir socialiniai bei ekonominiai sunkumai, kuriuos patyré visuomene, susidurdama su pragyvenimo sunkumais ir negalèdama skirti laiko ir energijos savanoriškai veiklai, už kurią nebuvo atlyginama. Savanoriška veikla dažnai suvokiama kaip trumpalaike, vienadienė veikla. Savanorystė yra populiariausia socialinejje, sveikatos, švietimo, kultūros srityse (Nacionalinè 2011-ųjų Europos savanoriškos veiklos, kuria skatinamas aktyvus pilietiškumas, metų programa, 2010).

Lietuvoje savanoriais laikomi asmenys, kurie laisva valia ir niekieno neverčiami dirba visuomenei naudingą darbą, negaudami atlygio [16].

„Vilmorus“ tyrimo apie nevyriausybinių organizacijų žinomumą ir savanorišką veiklą, atlikto 2012 metais, duomenimis, savanoriškoje veikloje dalyvauja tik 8 proc. Lietuvos gyventojų. Dažniau savanoriškoje veikloje dalyvauja besimokantis jaunimas (30 proc.), turintys aukštaji išsilavinimą (32 proc.) [2].

Suomijoje pradejjus vykdyti savanorišką veiklą, ji nebuvo labai vertinama, tačiau suprantama kaip grèsmè profesionaliam socialiniam darbui [5]. Reikšmingas požiūrio i savanorišką veiklą pakitimas įvyko 1990 - ujų viduryje. Savanoriškų organizacijų padidejimas buvo pastebimas socialineje rūpyboje ir sveikatos apsaugos srityse. Savanoriška veikla tapo pagrindiniu Suomijos visuomenès pilietiškumo elementu, atkreiptas dèmesys i savanoriškų organizacijų vaidmeni kuriant darbo vietas [20]. 
Nevyriausybinių organizacijų veiklos tyrinètojai M. Nylund (2000) ir A. B. Pessi (2008) apibrèžia savanorišką veiklą kaip neapmokestinamą veiklą, atliekamą laisva valia kitų labui. Ši veikla dažnai vyksta formaliai struktūriškai organizuotoje aplinkoje [20].

Savanoriškas darbas Suomijoje siejamas su asmens naryste. Apytiksliai $75-80$ proc. suomių yra savanoriškų organizacijų nariai, o daugelis jų - nariai keliose skirtingose organizacijose. V. Helander ir H. Laaksonen ịvertino, kad ịprastai Suomijos gyventojas yra trijų skirtingų organizacijų narys. Tai reiškia, kad reikšminga savanoriško darbo dalis yra atliekama organizacijos struktūros viduje [4].

Lyginant su kitomis Europos šalimis, Suomija yra pirmajame dešimtuke pagal piliečių dalyvavimą savanoriškoje veikloje. Eurobarometro tyrimo „Europos socialinè tikrove““, atlikto 2006 m., duomenimis, paaiškèjo, kad puse Suomijos gyventojų aktyviai dalyvauja savanoriškoje veikloje [20]. 2010 metu „Eurobarometro 73“ apklausos duomenys rodo, kad Suomijoje savanorystė populiaresnè tarp suaugusiujų žmonių [14].

Tyrimo tikslas - nustatyti būsimų socialinių darbuotojų nuostatas ị savanorišką veiklą.

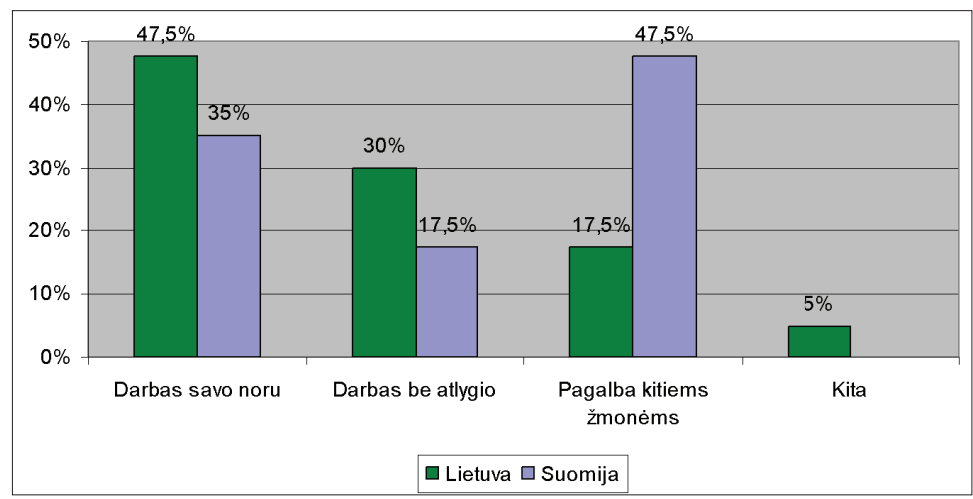

1 pav. Respondentų pasiskirstymas pagal tai, kaip jie supranta savanorišką veiklą

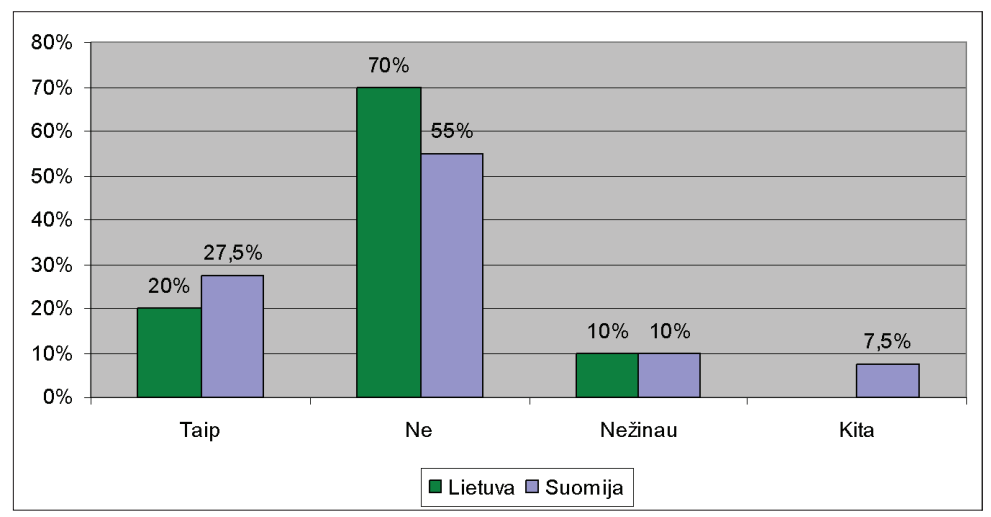

2 pav. Respondentų pasiskirstymas pagal tai, ar jų šalyje savanoriškai veiklai skiriama pakankamai dèmesio

\section{Tyrimo medžiaga ir metodai}

Tyrimo tikslui pasiekti organizuotas kiekybinis tyrimas, kurio metu vykdyta netikimybinè, patogioji, tikslinè atranka, atsižvelgiant $\mathfrak{i}$ šalį, kurioje gyvena respondentai, studijų programą ir kursą. Apklausta 40 Kauno kolegijos (Lietuva) ir 40 Tamperès kolegijos (Suomija) socialinio darbo nuolatinių studijų skyriaus II - III kurso studentų. Apklausa vykdyta lietuvių ir suomių kalbomis. Tyrimo instrumentą sudare 18 klausimų. Respondentai iš kelių teiginių variantų pasirinko ir žymèjo vieną, labiausiai jų nuomonę atitinkantị teiginį arba ịvertino juos Likert'o skaleje nuo 1 iki 5 , kur 1 reiškia visišką nesutikimą, o 5 - visišką sutikimą.

Instrumento konstrukcija buvo siekta atskleisti tyrimo dalyvių nuostatų i savanorišką veiklą kognityvinị, elgesio, emocinị komponentus, tyrimo dalyvių nuostatų i savanorišką veiklą kaitą per studijų metus ir priežastis, kurios tam turi įtakos. Atliekant tyrimą buvo vadovaujamasi etikos principais.

\section{Tyrimo rezultatai}

Empiriniu tyrimu siekta ištirti būsimų socialinių darbuotojų nuostatas ị savanorišką veiklą Lietuvoje ir Suomijoje, ivvertinant nuostatos kognityvini, emocini ir elgesio komponentus.

Tyrimo, vykdyto 2013m. Lietuvoje ir Suomijoje, metu buvo apklausta 80 respondentų. Respondentų grupé - socialinio darbo studijų programos antro ir trečio kursų studentai. Respondentai pagal amžių pasiskirsté ị grupes iki 24 metų Lietuvoje ir iki 29 metų Suomijoje.

Pažinimo (kognityvinis) komponentas susideda iš asmens žinių apie nuostatos objektą. Žinios, informacija yra vienas iš nuostatas formuojančių veiksnių. Informacijos pateikimas apie nuostatos objektą keičia jo suvokimą, interpretaciją [18]. Tiriant respondentu nuostatu i savanorišką veiklą kognityvini komponentą buvo klausiama, kaip respondentai supranta ir vertina savanorišką veiklą.

Tyrime dalyvavusių Lietuvos studentų grupejje beveik pusė 47,5 proc. respondentų savanorišką veiklą sieja su darbu savo noru, o studentų grupeje Suomijoje šios nuomonès yra trečdalis 35 proc. respondentų. Trečdalis respondentų lietuvių studentų grupeje mano, kad tai yra darbas be atlygio. Tuo tarpu Suomijoje beveik pusè 47,5 
proc. respondentų teigia, kad tai yra pagalba kitiems žmonėms. Rezultatai atskleidžia, kad studentai žino, kas yra savanoriška veikla (1 pav.).

Tyrimo metu respondentų prašyta ịvertinti, ar jų šalyje skiriama pakankamai demesio savanoriškos veiklos plètrai ir propagavimui (2 pav.).

Daugiau nei pusè respondentu (70 proc.) Lietuvoje ir Suomijoje (55 proc.) mano, kad savanoriškai veiklai vis dar neskiriama pakankamai dèmesio. Daugiau nei ketvirtadalis $(27,5$ proc.) respondentų grupejje iš Suomijos ir kiek mažiau nei 20 proc. respondentų grupejje Lietuvoje pripažįsta, kad, jų manymu, šiai veiklai skiriama pakankamai dèmesio. Galima daryti prielaidą, kad, respondentų nuomone, savanoriškai veiklai skiriamo dèmesio Lietuvoje ir Suomijoje nepakanka. Todèl aktualu skirti daugiau dèmesio savanoriškos veiklos propagavimui.

Nuostatos elgesio komponentas sąlygoja žmogaus reakciją, atitinkančią jo ịsitikinimus ir išgyvenimus $[9,18]$. Tiriant respondentų nuostatų ì savanorišką veiklą elgesio komponentą buvo siekiama išsiaiškinti, kokia yra respondentų savanoriškos veiklos patirtis (3 pav.).

Gauti duomenys parodè, kad respondentų savanoriškos veiklos patirtis yra labai ịvairi ir ženkliai skiriasi Lietuvoje ir Suomijoje. Matyti, kad didžiausi skirtumai išryškèja tarp dalyvaujančių ir nedalyvaujančių savanoriškoje veikloje. Savanoriškoje veikloje yra dalyvavę apie trečdalis (35 proc. ) respondentų Lietuvoje ir panašiai tiek pat (30 proc.) Suomijoje. Tačiau pastebima, kad šiuo metu dalyvaujančių Suomijoje yra daugiau nei trečdalis - 35 proc., kai Lietuvoje tarp dalyvaujančių tik 2,5 proc. Matyti, kad net trečdalis Lietuvoje 30 proc. ir du dešimtadaliai Suomijoje 22,5 proc. yra respondentu, kurie nedalyvauja, tačiau norètų dalyvauti. Kaip matyti 4 paveiksle dalyvavimo savanoriškoje veikloje procentas yra žymiai aukštesnis Suomijoje nei Lietuvoje. Tai atitinka ịvairių Europos tyrimų duomenis, kuriuose pabrèžiama, kad Suomija pasižymi vienu aukščiausių dalyvavimo savanoriškoje veikloje rodiklių Europoje, o Lietuva savo ruožtu užima vieną žemiausių vietų pagal dalyvavimą savanoriškoje veikloje.

Išsiaiškinta, kas respondentus skatina dalyvauti savanoriškoje veikloje. Lietuvoje respondentai dažniausiai sutiko, kad juos skatina noras igyti patirties ir žinių, nors Suomijoje respondentus tai skatina nežymiai. Lietuvoje ir Suomijoje respondentus panašiai skatina noras padèti kitam, noras tobulinti save, noras bendrauti, noras turiningai praleisti laisvalaikị. Galima teigti, kad patirtis ir žinios yra labiausiai skatinanti priežastis dalyvauti savanoriškoje veikloje Lietuvoje. Patirties ịsivardijimas motyvuoja savanorį, nes konkrečių profesinių, asmeninių, socialinių kompetencijų bei žinių gavimas patvirtina savanoriškos veiklos prasmę kiekvienam savanoriaujančiam per jo asmeninę patirti [16].

Kadangi yra daug nedalyvaujančių savanoriškoje veikloje apklaustujų, buvo siekiama išsiaiškinti jų nedalyvavimo savanoriškoje veikloje priežastis (4 pav.).

Suomijoje besimokančių respondentų grupejje visi vieningai teigè, kad nedalyvauja dèl laiko stokos, o Lietuvoje studijuojančiųjų respondentu grupejje šią priežastị nurodè 46,1 proc. tyrimo dalyvių. Du penktadaliai $(38,5$ proc.) respondentų Lietuvoje teigé, kad trūksta informacijos apie savanorišką veiklą. Dar dešimtadalis ( 7,7 proc.) Lietuvoje yra manančių, kad jie negali būti naudingi, todèl nedalyvauja, o „kita“ pasirinkę (7,7 proc.) nurodè tokias priežastis: ,prasta ekonominè situacija“, „pinigų trūkumas“. Nors Lietuvoje respondentų nuostatų ko-

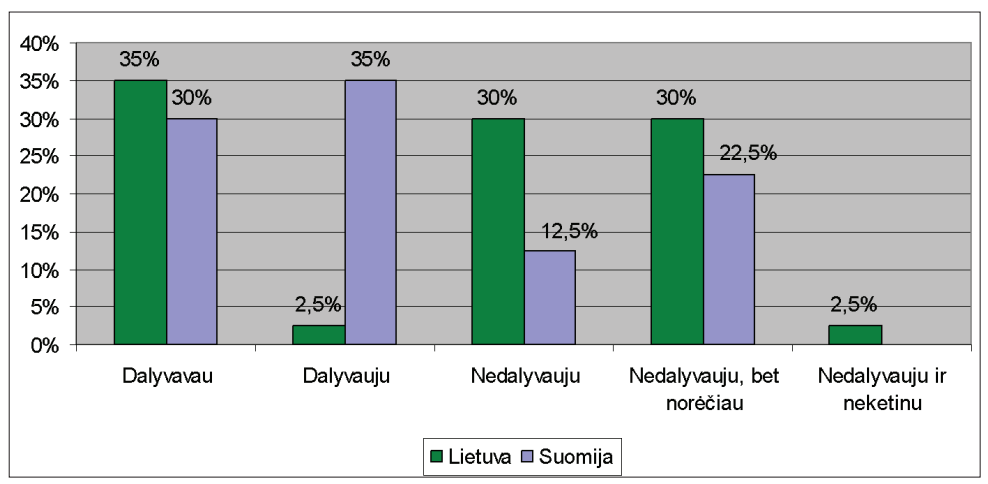

3 pav. Respondentų pasiskirstymas pagal turimą savanoriškos veiklos patirtị

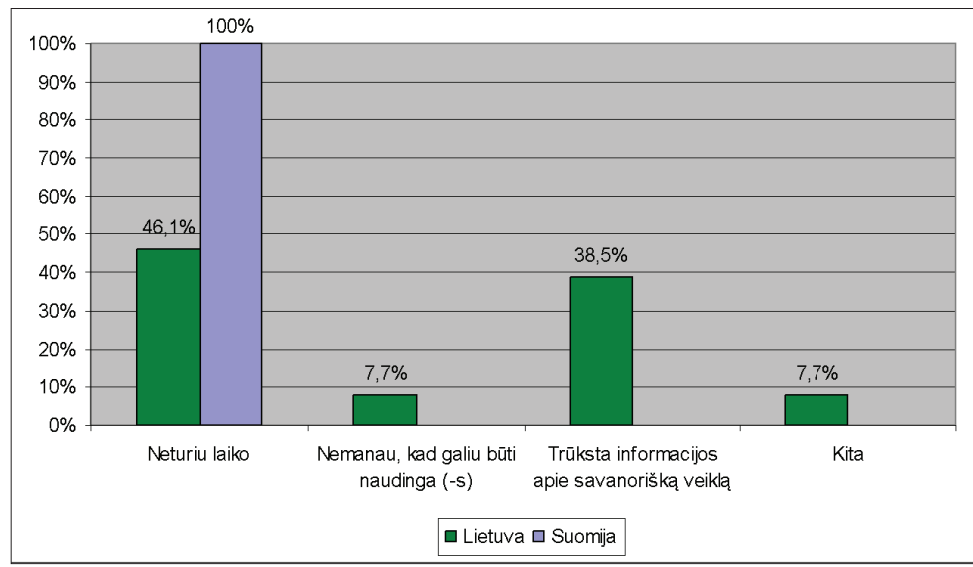

4 pav. Respondentų pasiskirstymas pagal nedalyvavimo savanoriškoje veikloje priežastis 


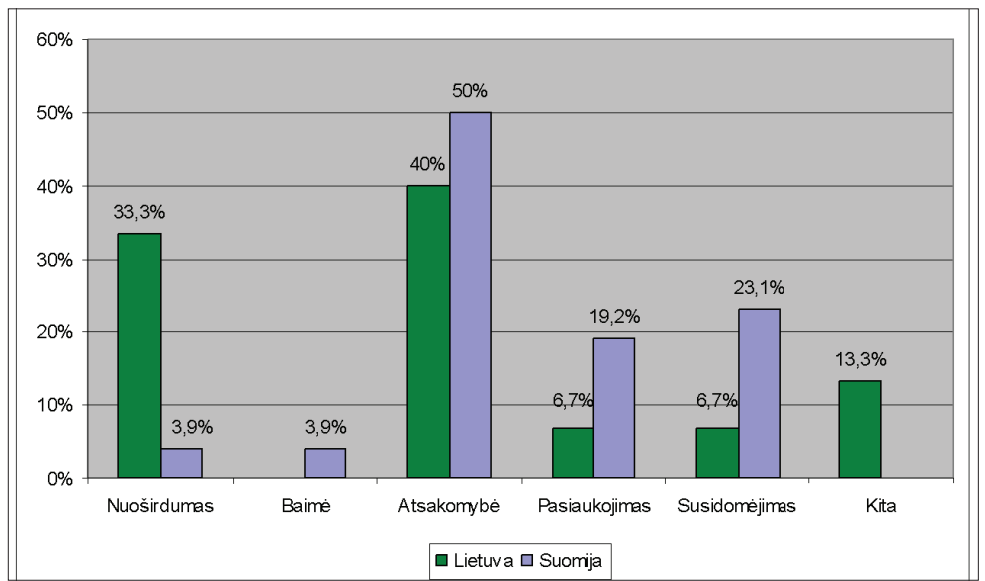

5 pav. Respondentų pasiskirstymas pagal tai, kokius jausmus išgyveno dalyvaudami savanoriškoje veikloje

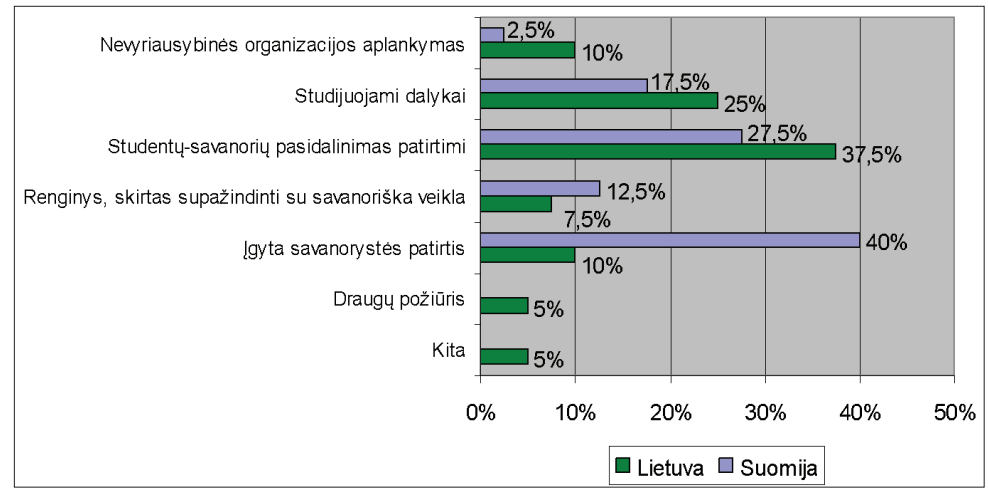

6 pav. Respondentų pasiskirstymas pagal tai, kas studijų metu gali turèti ịtakos nuostatoms ị savanorišką veiklą

gnityvinis komponentas yra teigiamas savanoriškos veiklos atžvilgiu, tačiau dalyvavimas nèra aktyvus. Galima daryti prielaidą, kad respondentai stokoja informacijos apie dalyvavimo savanoriškoje veikloje galimybes.

Emocinis nuostatos komponentas apima malonias ir nemalonias emocijas, kurios suteikia nuostatai emocinị atspalvị ir gali nulemti informacijos priemimą arba ketinamą vykdyti veiksmą. Tiriant respondentų nuostatų ị savanorišką veiklą emocinị komponentą išsiaiškinta, kad abiejų šalių respondentai savanorišką veiklą dažniausiai sieja su pozityviais jausmais ( 5 pav.).

Pusè respondentų (50 proc.), dalyvavusių savanoriškoje veikloje, Suomijoje ir šiek tiek mažiau nei puse (40 proc.) Lietuvoje, išgyveno atsakomybės jausmą. Lietuvoje besimokantys respondentai ịvardijo nuoširdumo jausmą, kuri patiria savanoriškos veiklos metu (33,3 proc.). Suomijoje du dešimtadaliai apklaustujų ( 23,1 proc.) išgyveno susidomejjimo jausmą ir pasiaukojimo jausmą (19,2 proc.). Vienas respondentas Suomijoje pripažino, kad patyrẻ baimę dalyvaujant savanoriškoje veikloje. Prie galimų alternatyvų, tyrimo dalyviai nurodè išgyvenę ,permainingus, ịvairius jausmus“ (13,3 proc.). Apibendri- nant galima teigti, kad savanoriška veikla skatina ịvairius teigiamus jausmus, o įsitraukimas ị ją sąlygoja didesnę atsakomybę už atliekamą veiklą.

Tyrimu atskleista, kad, daugumos respondentų manymu, jų nuostatos i savanorišką veiklą pasikeite studijų metu. Siekiant nustatyti nuostatu pasikeitimą lemiančias priežastis, respondentu prašyta nurodyti, kas studijų metu gali turèti įtakos nuostatoms ị savanorišką veiklą (6 pav.).

Lietuvoje daugiau nei trečdalio (37,5 proc.) respondentų, o Suomijoje - kiek mažiau (27,5 proc.) manymu, studentu - savanorių pasidalijimas patirtimi turetu itakos tyrimo dalyvių nuostatoms. Tuo tarpu Suomijoje net 40 proc. studentu nurodo, kad pačiu ịgyta savanoriško darbo patirtis gali turèti itakos nuostatų formavimui. Lietuvoje taip mano tik nedidelè dalis - 10 proc. Ketvirtadalis (25 proc.) Lietuvoje ir beveik du dešimtadaliai (17,5 proc.) Suomijoje respondentų mano, kad patirtis studijuojant ịvairius studijų dalykus daro įtaką nuostatų formavimuisi ir yra svarbi. Studijų metu igytos naujos teorinès ir praktinès žinios transformuojasi $i$ asmeninę patirtí, paveikia nuostatos kognityvini komponentą ir keičia nuostatas. Nuostatos geriau įsitvirtina ir viena ar kita kryptimi keičiasi, kai individas savo patirtimi patikrina vienus ar kitus argumentus ir aktyviai juos panaudoja veikloje [18]. Respondentų iš Suomijos grupejje asmeninė patirtis laikoma reikšmingiausia nuostatoms formuotis. Tyrimo dalyvių iš Lietuvos grupejje svarbiausia yra kitų asmenų turima patirtis, kuria pasidalijama.

\section{Išvados}

Remiantis atlikto tyrimo duomenu analize, galima teigti, kad respondentų nuostatų i savanorišką veiklą kognityvinis komponentas yra panašiai išreiškiamas abiejose respondentuc grupése - tiek Lietuvoje, tiek ir Suomijoje. Respondentai žino, kas yra savanoriška veikla, teigiamai vertina jos teikiamą naudą būsimojo socialinio darbuotojo tobulejjimui. Respondentai išreiške išsamesnès informacijos apie savanorišką veiklą poreikị.

Nustačius respondentų nuostatų i savanorišką veiklą elgesio komponentą, paaiškejjo, kad tarp turinčių savanoriškos veiklos 
patirties yra trečdalis respondentų Lietuvoje ir net du trečdaliai respondentų Suomijoje. Dažniausiai savanoriškoje veikloje nedalyvaujama dèl laiko stokos, kurią nurodè visi respondentai Suomijoje ir pusè respondentų Lietuvoje. Trečdalis respondentų Lietuvoje nedalyvauja savanoriškoje veikloje, nes trūksta informacijos.

Identifikavus respondentų nuostatų ị savanorišką veiklą emocini komponentą, paaiškèjo, kad abiejose šalyse savanoriška veikla siejama su teigiamais jausmais, o labiausiai su pasiaukojimo jausmu, kurị nurodè trečdalis respondentų Suomijoje ir maždaug pusè respondentų Lietuvoje. Savanoriška veikla dalyvaujantiems ugdo atsakomybės jausmą. Respondentai iš abiejų šalių pažymèjo, jog jų nuostatos ị savanorišką veiklą studijų metu pasikeitè.

\section{Literatūra}

1. Abramavičienė I. Psichologinė pagalba telefonu, 2010. Prieiga per internetą $<$ http://www.google.lt/url?sa $=\mathrm{t} \& \mathrm{rct}=\mathrm{j} \& \mathrm{q}=\&$ esrc $=\mathrm{s} \&$ source $=$ web\& $\mathrm{cd}=1 \&$ ved $=0 \mathrm{CCsQFj} A \mathrm{~A} \&$ url $=\mathrm{http} \% 3 \mathrm{~A} \%$ 2F\%2Fwww.sppd.lt\%2Flibrary\%2Fjs\%2Ftiny_mce\%2Fplugins $\% 2$ Fsimplebrowser $\% 2$ Fassets $\% 2$ Ffile $\% 2$ FMokymo $\% 252$ 0progr-leid-psichol-pag-telefonu-10> [Žiūrèta 2012-10-10].

2. Europoje vyraujančių savanorystės modelių analizè. Vilmorus" atliktas tyrimas, 2012. Prieiga per internetą<http://ec.europa.eu/ lietuva/documents/power_pointai/savanorystes_tyrimas_2011. pdf $>$ [Žiūrèta 2015-09-15].

3. Gailienè D., Bulotaitė L., Sturlienė N. Asmenybės ir bendravimo psichologija. Vadovèlis XI-XII klasėms. Vilnius, 2002.

4. Grönlund H. Volunteerism as a mirror of individuals and society: reflections from young adults in Finland, 2012. Prieiga per internetą $<$ https://helda.helsinki.fi/bitstream/handle $/ 10138 / 32919 /$ voluntee.pdf? sequence $=1>$ [Žiūrèta 201508-25].

5. Hilger PA. Case of Human Service Dominance: Volunteer Centres in Finland Volunteering Infrastructure and Civil Society Conference, 2008. Prieiga per internetą<http://www. mv.helsinki.fi/home/hilger/downloads/pdf/Hilger_Volunteer_centres in_Finland080616.pdf $>$ [Žiūrèta 2014-11-05].

6. Johnson L. C. Socialinio darbo praktika. Bendrasis požiūris. Vilnius, 2003.

7. Jonutytė I. Savanorystė socialinio ugdymo sistemoje. Monografija. - Klaipėda, Klaipėdos universitetas, 2007.

8. Kriaučiūnienė R. Dorinè nuostata kaip mokslinio pažinimo objektas// Mokslo darbai. Acta Pedagogica Vilnensia [interaktyvus]. 2007; Nr.18. Prieiga per internetą< http://www. leidykla.eu/fileadmin/Acta_Paedagogica_Vilnensia/18/str7. pdf $>$ [Žiūrèta 2012-10-02].

9. Kučikas A., Norvila J., Kurtinaitytė G., Kurapkaitienė N., Borovskaja O., Kėžaitė M. Straipsnių rinkinys apie savanorišką veiklą. Kaunas, 2007.

10. Legkauskas V. Socialinè psichologija. Vilnius, 2008.
11. Lietuvos gyventojų nuostatų ir atvirumo savanorystès idejai studija. TNS Gallup" tyrimas Lietuvos Anatomija", 2008. Prieiga per internetą <http://www.teo.lt/gallery/Dokumentai/ ziniasklaidai/Savanoryste_TNS.pdf $>$ [Žiūrèta 2014-08-12].

12. LR Savanoriškos veiklos įstatymas. Valstybès žinios XI-1500, 2011-07-13, Nr. 86-4142 [Žiūrèta 2015-01-12].

13. Myers D. G. Psichologija. Vilnius, 2000.

14. Myllyniemi S. Information sheet. Volunteering of young people. Finland, 2011. Prieiga per internetą < http://youth-partnership-eu.coe.int/youth-partnership/documents/Questionnaires/ Voluntary_activities/Volunteering_2011/Information_sheet volunteering_of_young_people_finland_2011.pdf> [Žiūrèta 2012-10-02]

15. Sakalauskas G., Nikartas S. Kas yra savanorystė?//Savanorystė probacijos sistemoje: prielaidos ir galimybès. Vilnius, 2012.

16. Saulaitis A. Savanorystės organizavimas bendruomenèje//Socialinis darbas. Profesinė veikla, metodai ir klientai. Vadovèlis. Vilnius, 2010.

17. Skruibienè I., Polukordienė K. O. Savanorių pritraukimo ir motyvavimo programa, 2010. Prieiga per internetą<http:// www.jppc.lt/jppc/admin/spaw2/uploads/files/Savanoriu $\% 20$ pritraukimo $\% 20 \mathrm{ir} \% 20$ motyvavimo $\% 20$ programa.Be $\% 20$ Carito._2010\%2003\%2031.pdf> [Žiūrèta 2010-10-02].

18. Suslavičius A. Socialinė psichologija studentams ir ne tik. Vilnius, 2006.

19. Šikšta A. Savanorystė Lietuvoje: Kas? Kaip? Kur? Vilnius, 2008.

20. Vikström J, Raitanen A. Chapter 9 Finland//Volunteering infrastructure in Europe, 2012. Prieiga per internetą< http://issuu. com/european_volunteer_centre/docs/chapter-9---finland $>$ [Žiūrèta 2012-10-02].

\section{THE ATTITUDES OF FUTURE SOCIAL WORKERS TOWARD VOLUNTEERING: LITHUANIAN AND FINNISH EXPERIENCE}

I.Kupčikienė, E.Stasiūnaitienė, S.Palažijūtė

Key words: volunteering, attitude, social worker.

Summary

Volunteering complements a professional support and is one of the major activities in the field of social work. Every future social worker evaluates and understands volunteering based on the number of attitudes that may have an impact on professional work and assistance, so it is important to find out their prevailing attitudes. Attitudes to volunteering in Lithuania and Finland are a relatively new research area.

Aim of the work: to explore the attitudes of future social workers toward volunteering in Lithuania and Finland.

Research methods: A descriptive quantitative study based on the cognitive, emotional and behavioral components of the attitude. 40 students of social work study program from Kaunas College (Lithuania) and 40 students from Tampere College (Finland) were interviewed.

Research question: What are the attitudes of future social 
workers toward volunteering in Lithuania and Finland?

Work object: Attitudes of future social workers toward volunteering in Lithuania and in Finland.

Research outcomes:

According to the survey data analysis, a cognitive component of the respondents' attitudes towards volunteering is similarly expressed in both countries. All of the respondents know what volunteering is and positively evaluate the benefits to a future social worker and the public.

Examination of the behavioral component of the respondents' attitudes towards volunteering showed that one-third of respondents in Lithuania and two-thirds of the respondents in Finland have volunteering experience. All the respondents in Finland and half of the respondents in Lithuania do not participate in volunteering due to the lack of time; one-third of respondents in Lithuania do not participate due to the lack of information.

Examination of the emotional component of respondents' attitudes showed that volunteering is associated with positive feelings in both countries, and most of all with a sense of selfsacrifice, which was pointed out by one-third of the respondents in Finland, and about half of the respondents in Lithuania. Half of the respondents in both countries said that their attitudes to volunteering have changed over the years of study.

Correspondence to: egle.stasiunaitiene@go.kauko.lt

Gauta 2015-09-29 